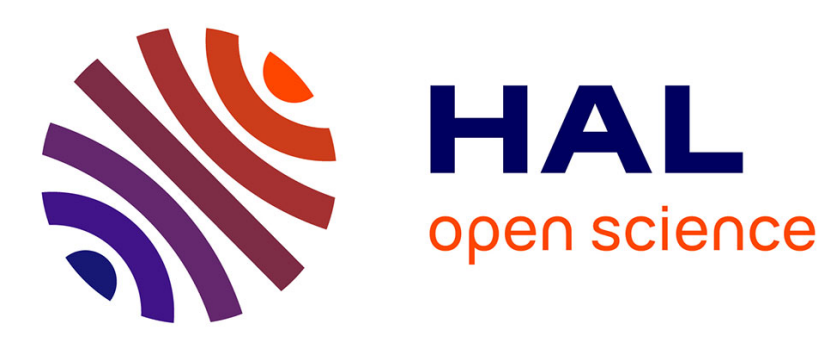

\title{
LASER CLADDING ON ALUMINIUM BASE ALLOYS
}

M. Pilloz, Jean Pelletier, A. Vannes, A. Bignonnet

\section{To cite this version:}

M. Pilloz, Jean Pelletier, A. Vannes, A. Bignonnet. LASER CLADDING ON ALUMINIUM BASE ALLOYS. Journal de Physique IV Proceedings, 1991, 01 (C7), pp.C7-117-C7-120. 10.1051/jp4:1991724 . jpa-00250927

\section{HAL Id: jpa-00250927 https://hal.science/jpa-00250927}

Submitted on 1 Jan 1991

HAL is a multi-disciplinary open access archive for the deposit and dissemination of scientific research documents, whether they are published or not. The documents may come from teaching and research institutions in France or abroad, or from public or private research centers.
L'archive ouverte pluridisciplinaire HAL, est destinée au dépôt et à la diffusion de documents scientifiques de niveau recherche, publiés ou non, émanant des établissements d'enseignement et de recherche français ou étrangers, des laboratoires publics ou privés. 


\title{
LASER CLADDING ON ALUMINIUM BASE ALLOYS
}

\author{
M. PILLOZ, J.M. PELLETIER, A.B. VANNES* and A. BIGNONNET** \\ GEMPPM-CALFETMAT, Bât. 403, INSA, F-69621 Villeurbanne cedex, France \\ ${ }^{*}$ MMP-CALFETMAT, ECL, BP. 167, F-69631 Ecully cedex, France \\ **PSA-DRAS, Centre Technique Cüroen, F-78140 Vélizy, France
}

\begin{abstract}
In the present work, this method is employed on aluminum alloys; nickel or silicon are added by powder injection. Addition of silicon leads to sound surface layers, but with moderated properties, while the presence of nickel induces the formation of hard intermetallic compounds and then to an attractive hardening phenomena; however a recovery treatment has to be carried out, in order to eliminate porosity in the near surface region.
\end{abstract}

\section{I - Introduction :}

During the last decade, many studies have been reported concerning the different possibilities offered by surface treatments of metallic materials. Among them, laser cladding and laser surface alloying appear especially attractive, due to their specific features $(1,2,3)$ :

- large variations of both width and depth of the treated zone may be obtained,

- a metallurgical bonding is achieved between substrate and cladding, inducing an ahesion larger than those obtained with other thermal projection methods (plasma spraying, flame deposition...).

This processing has been developed on iron or titanium base alloys, but not on aluminium alloys. Now, for many industrial applications, surface treatment have to be performed on these materials, in order to improve their tribological properties, especially their wear resistance (4). Therefore, tests have to be made on such materials.

Several elements could be used as powder components; indeed a brief survey of equilibrium phase diagrams indicates that many elements form intermetallic compounds with aluminium, e.g. $\mathrm{Ni}, \mathrm{Co}, \mathrm{Cr}, \mathrm{Ti}$ or Fe, and therefore could induce a large improvement of mechanical properties. Nickel was retained in the present study, due to the following advantages :

- nickel is a stable element, with a good oxydation resistance,

- many intermetallic compounds can be obtained : $\mathrm{Al}_{3} \mathrm{Ni}, \mathrm{Al}_{3} \mathrm{Ni}_{2}, \mathrm{Al}_{5} \mathrm{Ni}_{3}, \mathrm{AlNi}, \mathrm{AlNi}_{3}$.

- Al rich Al-Ni alloys have a low liquidus temperature, compared for example with similar Al-Ti alloys : $\mathrm{T}_{\mathrm{L}} \approx 800^{\circ} \mathrm{C}$ for $\mathrm{Al}-10 \mathrm{at} \% \mathrm{Ni}$, instead of $\approx 1200^{\circ} \mathrm{C}$ for $\mathrm{Al}-10$ at.\% Ti. So a larger temperature range will be allowed for homogeneization of the surface layer, due a longer lifetime of the melt pool.

In addition, cladding with Si of hypoeutectic Al-Si alloys will be performed, in order to increase the Si surface content.

\section{II - Experimental procedure:}

The substrate (AS7O.3G) had the following composition : A1 - 7\%SI - 0.3\% Mg. Parallelepipedic samples $\left(70 * 30 * 10 \mathrm{~mm}^{3}\right)$ were grit blasted before coating. Two powders were injected, either Al-12\% $\%$ or Ni$4 \%$ Al. particlez sizes were between 40 and $120 \mu \mathrm{m}$. Specimens were mounted on a numerically controlled $\mathrm{X}-\mathrm{Y}$ table and irradiated with a $\mathrm{CW} \mathrm{CO} 2$ laser, the power of which was up to about $3.6 \mathrm{~kW}$. Laser beam 
was focused by a spherical $5^{\prime \prime} \mathrm{ZnSe}$ lens. Focus point was located $20 \mathrm{~mm}$ above the surface of the sample and the diameter of the irradiated zone was about $\mathrm{mm}$.

Scanning rate $V$ was about $2 \mathrm{~cm} / \mathrm{s}$. Powder was injected using a 4MP Metco spray system, with a lateral injection nozzle. Argon was blown in order to reduce oxydation during melting.

For optical or scanning electron microscopy and harness measurements, samples were cutted and polished down to $1 \mu \mathrm{m}$. Etching with $\mathrm{NaOH} \mathrm{10 \% )} \mathrm{was} \mathrm{used} \mathrm{for} \mathrm{optical} \mathrm{observations.} \mathrm{X-ray} \mathrm{diffraction} \mathrm{experiments}$ were carried out with $\mathrm{Cu} \mathrm{K} \alpha$ radiation.

\section{III - Laser cladding with Al-Si powder :}

A typical aspect of the laser cladded sample is shown on fig. 1. Several remarks may be made :

- some porosities are observed, but no cracks may be detected,

- a metallurgical bonding has been produced by this processing. Indeed transition in the interfacial

zone is not sharp,

- a dentritic microstructure is observed, from the bottom to the top of the surface layer. No plane front growth zone is evidenced.

X-ray diffraction experiments indicate the presence of only two stable phases : $\mathrm{Al}$ and $\mathrm{Si}$, exactly as in the substrate.

Hardenig effect is limited : $\mathrm{Hv} \approx 150$ in the cladding, compared with $\approx 95$ in the substrate. These results are in agreement with those reported by various authors $(5,6)$. Two reasons may be considered : the silicon content is not high enough $(\approx 10-15 \%)$ - but a two large value induces an excessive brittleness - and formed phases are not very hard, since no intermetallic compounds is detected. So this solution is not especially attractive.

\section{IV - Laser cladding with Ni-Al powder :}

In a first time, some experiments have been carried out with $\mathrm{Ni}-4 \% \mathrm{Al}$ powder. However, despite many attempts of optimization, no sound cladding have be achieved : in all the cases, nickel melts on the surface, without the formation of a surface alloy and, due to a lack of wettability, no mixing is obtained. So this solution has been given up.

It is well known that silicon has a favourable effect on the surface tension of aluminium alloys (7). So pure $\mathrm{Ni}$-base powder was replaced by a mixture of Ni-base and Al-Si base powders. Relative amounts are the followings : $\mathrm{Ni}(10 \%)$ - $\mathrm{Si}(10 \%)$ - $\mathrm{Al}(80 \%)$. After a single pass, a large number of holes is observed in the cladding (fig. 2). These porosities appear in the whole volume and if their size and density depend on processing conditions (laser power, scanning rate, powder feed rate, defocusing distance, they are always present in the surface layer. A partial solution was found : after the first laser cladding pass, a second melting was achieved, without powder injection, on the same area. Laser processing conditions are very similar in both cases. Fig. 3 shows the micrographic aspect after the two-stages treatment : porosity is still observed in the bottom of the cladding, but a surface recovery has been achieved. It may be expected that for thinner claddings this recovery can be complete, but in the present experimental conditions, this was not possible. An increase of either laser power or interaction time should induce an increase of both temperature and lifetime of the melt pool and therefore to an enhancement of the convection movements which allows the vanishing of these holes. However irradiance on the sample cannot exceed a critical value; indeed beyond this value, a plasma is formed above the surface and then laser-material interaction is fully different and no beneficial effect is obtained (4).

This surface recovery is simillar to data reported in the litterature concerning laser surface melting of plasma predeposited layers, especially ceramic coatings $(8,9)$. In both cases, laser melting induces a flat and inpenetrable barrier on the substrate.

Various assumptions may be formulated concerning the origin of this porosity :

- the substrate is a cast alloy and different gas are included during the casting operation. Surface melting could produce a coarsening effect. The same phenomenon was reported in different aluminiumsilicon base alloys, even in a vacuum environment (10).

- during powder injection, a feeding gas is used (argon), and it could be assumed that this incoming gas will be "enclosed" in the final cladding. 
To conclude, further experiments have to be performed, with other processing conditions and with other materials (substrates or powders).

In all the cases, a fine and dendritic microstructure is observed (Fig. 4). After a single pass treatment, both optical microscopy and X-ray diffraction experiments reveal the existence of undissolved particles of nickel, while after a two-passes treatment, only aluminium and intermetallic compounds ( $\mathrm{Al}_{3} \mathrm{Ni}, \mathrm{AL}_{3} \mathrm{NI}_{2}$ ) are detected. Their existence induces a large hardening effect; for instance, hardness values up to 300 $\mathrm{HV}_{0.2}$ have been obtained; this value is measured in the whole surface layer.

\section{Conclusion :}

Laser cladding on Al-base alloys appears more difficult than on $\mathrm{Fe}$ - base alloys. These difficulties may originate from differences of wettability (surface tension effects) and from the existence of included gas in cast aluminium base alloys. However from these first attempts, different points can be retained :

- addition of silicon is possible (fairly easily),

- addition of nickel requires a two-stages treatment; the second melting, without powder injection, induces a surface recovery; then a sound near surface region is achieved, with a hardness up to $300 \mathrm{HV}_{0.2}$.

\section{References :}

A/ DRAPPER, C.W, J. of Metals, 34 (1982) 24.

/2/ DRAPPER, C.W. and POATE, J.M., Int. Metals Rev., 30 (1985) 85.

13/ SINGH, J., MAZUMDER, J., Metall. Trans., 18A (1987) 313.

/4/ GAFFET, E., PELLETIER, J.M. and BONNET-JOBEZ, S., Acta Metall., 37 (1989) 3205.

15/ ALBERT, D., VEIT., S. and MERGEN, R., J. de Phys., C7, 48 (1988) 4.

/6/ MORDIKE., S. , Laser VI, IITT eds, Paris (1990), 99.

$7 /$ HATCH., J.E., in "Aluminium Properties and Physical Metallurgy", ASM, Metals Park, Ohio (1988).

/8/ PETITBON, A. and GUIGNOT,D., Mat. Sci. Eng., A121 (1989) 545.

/9/ JASIM, K.M., WEST, D.R.F., STEEN, W. and RAWLINGS, R.D., Proc. ICALEO, 30 Oct.- 4 Nov. 1988, Santa Clara, Cal., USA, Springer Verlag ltd, UK, p. 17-31.

/10/ VANHILLE, P. , private communication. 

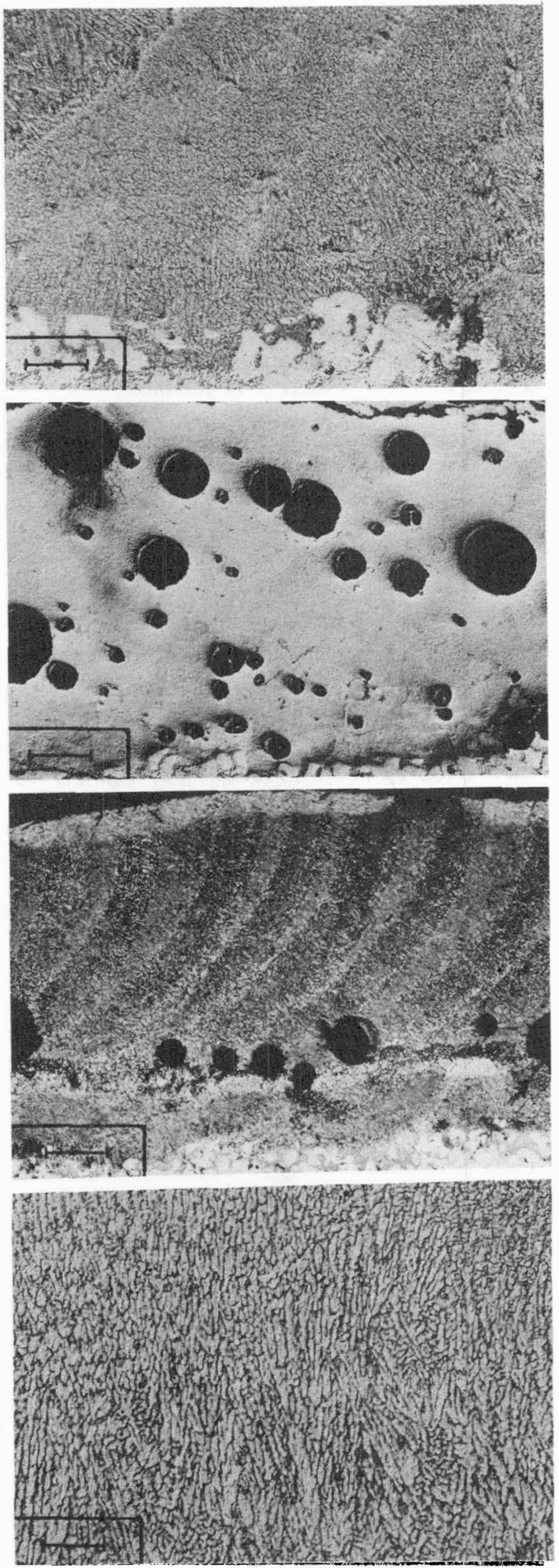

Fig. 1 : micrography of an Al-Si coating on an $\mathrm{Al}$-Si base alloy; $P=1500 \mathrm{~W} ; \mathrm{V}=2 \mathrm{~cm} / \mathrm{s}$; feed rate : $6 \mathrm{~g} / \mathrm{mn} ; \mathrm{G}=125$.

Fig. 2 : micrography of an $(\mathrm{Al}-\mathrm{Si})+(\mathrm{Al}+\mathrm{Ni})$ coating on an Al-Si base alloy after a single pass treatment; $P=1500 \mathrm{~W} ; \mathrm{V}=2 \mathrm{~cm} / \mathrm{s}$; feed rate $: 7.2 \mathrm{~g} / \mathrm{mn} ; \mathrm{G}=62.5$.

Fig. 3 : micrography of an (Al-Si) $+(\mathrm{Al}+\mathrm{Ni})$ coating on an Al-Si base alloy after a two-pass treatment; $\mathrm{P} 1=1500 \mathrm{~W} ; \mathrm{V} 1=2 \mathrm{~cm} / \mathrm{s} ;$ feed rate : $7.2 \mathrm{~g} / \mathrm{mn} ; \quad \mathrm{P} 2=1800 \mathrm{~W} ; \mathrm{V} 2=1 \mathrm{~cm} / \mathrm{s}$; defocusing distance : $12 \mathrm{~mm} ; \mathrm{G}=50$.

Fig. 4 : dendritic microstructure of the laser (Ni-Si-Al) laser cladding on Al-Si base alloy; same conditions as in fig. $3 ; \mathrm{G}=400$. 